\title{
THE ROLE OF CIVIL SOCIETY IN THE WAR OF INDONESIA INDEPENDENCE: A CASE STUDY IN THE BATTLE AGAINST THE ALLIED FORCES IN SUKABUMI 1945-1946
}

\begin{abstract}
Sulasman ${ }^{1}$
ABSTRACT

The revolution of Sukabumi is closely related to the role of many kyai, ulama and pesantren's leaders in its process. They had great power to encourage people's spirit and emotion. This success was gained by using their religious language to communicate. They used the concept of jih ad fi sabilillah. The climax of the revolution is the battle against the invader's alliance along the road ofCigombong-Ciranjang thatwas followed by a series of battle,such as Bojongkokosan battle,causing the bombing of Cibadak by Alliance air force; Gekbrong battle; and general attack involving army force, ulama, people's organization and the students of pesantrens.
\end{abstract}

Key Words: revolution, strategy, tactic, battle, diplomacy

\footnotetext{
${ }^{1}$ Sulasman is lecture lecturer of Islamic History and Civilization Departement at Adab and Humanities Faculty at State Islamic University (UIN) Sunan Gunung Djati Bandung. For academic interest, the author can be contacted at E-mail: sulasman14@yahoo.com.
} 


\section{Introduction}

In the beginning, Sukabumi was part of Kabupaten Cianjur. In 1776, the Sukabumi region was changed into Kepatihan through name of Kepatihan Cikole by the Bupati of Cianjur the sixth named Raden Noh or Aria Wiratanoedatar VI. Later, the name of Cikole was changed into Sukabumi by Andries de Wilde. There were two government sites in Sukabumi region;they were Kotamadya Sukabumiand Kabupaten Sukabumi. In the beginning, administratively both of the governments were part of Karesidenan Priangan, where West Priangan consisted of Sukabumi and Cianjur, then based onBesluit Number 16 dated on October 15th 1931,both region became part of Keresidenan Bogor.(Nina Herlina Lubis,1998:34).

Sukabumi, like on the Memoreis van Oveegave Residen L. de Steurs (1921) had high economical position in the plantation sector, and became one of the most financial mainstay of the Netherland Indies Government to bail out the financial bankruptcy caused by the "Perang Jawa" (Haryoto Kunto, 1991: 21). In the Japanese Era, plantation in Sukabumi became the holder of economic for war programs (Aiko Kurasawa, 1993: 49-53). In the revolution age, the plantation became the source of the fund, especially when facing the Allies troops.

The government of Netherland Indies made the city of Sukabumi as Gemeente on April 1st 1914. Its status later was increased to become Stadgemeente on Mei 1st 1926. The city of Sukabumi was made as a place for political excommunication by the Netherland Indies Colonial Government (Ruyatna Jaya, 2002: 30). The political figures excommunicated to Sukabumi were
Cut Nyak Dien (Ruyatna Jaya, 2002: 30), Mohammad Hatta, (Mohammad Hatta, 1982:383-386),TjiptoMangoenkoesoemo, (R.Z. Leirissa, 1992: 120) and Sutan Syahrir (Sutan Syahrir, 1990: 247).

\section{Taking Over the Authority in Sukabumi}

Revolution in Sukabumi began through the taking over of the authority from Japan. In the process of preparing that matter, the National Committee of Local Indonesian (Komite Nasional Indonesia Daerah) had been established led by Dr. Abu Hanifah (Abu Hanifah, 1972) and the Agency of People Security (Badan Keamanan Rakyat) led K.H. Atjoen Basoeni also established. The member of BKR in Sukabumi mainly consisted of the former soldiers of PETA. After K.H. Atjoen Basoeni disappeared and never returned to Sukabumi (Eddie Soekardi, interviewed on April 4th 2004), his position was succeeded by Eddie Soekardi (Soebarna, interviewed on March 17th 2004).

Besides BKR, there were also organizations in Sukabumi such as Pesindo led by Waluyo, Barisan Islam Indonesia by K.H. Ahmad Sanoesi, Hizbullah by K.H. Damanhoeri,Sabilillah by A. Basarah, Barisan Banteng by Lunadi, Lasykar Rakyat by Sambik, Digulis by Basuki (Panitia Pembangunan Monumen Perjuangan 45 Kabupaten Sukabumi, 1986: 8).

In the process of taking over the authority, there were the view's differences among all. Pemuda (young) wanted to take over the authority done as fast as possible, whereaskelompoktua(old)supportedbythe former PETA soldiers and HEIHO soldiers wanted to take over the authority through peace and negotiation (Abu Hanifah, 1972: 
176). Beside the age factor, the condition was also based on the place of meeting like Kelompok Cikiray (Cikiray Group) 10 B ((Panitia Pembangunan Monumen Perjuangan 45 Kabupaten Sukabumi, 1986: 11) includes Edeng Abdullah, Waluyo, Djakaria, A.M. Sipahutar, Adang Trenggana, Bainun, and Ading Rifa'i and kelompok Asrama Nogyo Gakko (Asrama Nogyo Gakko Group) which consist of Dr. Abu Hanifah, Mr. Syamsudin, Gatot Mangkupradja, Soebarna, Suradiradja, Setiaatmadja, R. Didi Soekardi, Iskandar, Sukatma, M. Barnas.

In avoiding conflict, there were meeting conducted among the figures. The agreement resulted was that before the taking over the authority there should be a delegation headed by K.H. Atjoen Basoeni to meet the Shuchokan in Bogor to hand over the authority. The other decision of the agreement was forcing to take over of the authority if the mission led by K.H. Atjoen Basoeni failed. The leader of that movement was S. Waluyo, K.H. Damanhoeri, Edeng Abdullah, and BKR.

On October 1st 1945, K.H. Atjoen Basoeni announced his fail to get the authority handover from Japan. That information made people of Sukabumi who gathered in front of Societet Soekamanah Soekaboemi hall angry. The anger of people could not be stopped, the revolution flame was lightened and the spirit of revolution was established, they moved to every directions aimed to take over the authority, and it was begun by taking over the headquarter Kempeitai and also freeing the prisoners. After that, they seized the government offices and so on.

Besides seizing the symbol of authority, revolution in Sukabumi was also marked by the positioning of new official governor like Mr. Syamsudin as city mayor of Sukabumi, Mr. Harun as Bupati of Sukabumi (Abu Hanifah, 1972: 180). The taking over of the authoritymoved continuouslytokecamatan (district) even to the villages, and also with its substitution of the office holder. The new official governors and office holders mainly came from pesantren (kind of monastery in Islamic culture) like wedana of Cicurug by Ajengan Ansori, wedana of Cibadak by Ajengan Syafe'i, wedana of Pelabuhan Ratu by Ajengan Hafid, and wedana of Jampang by Ajengan Hulaemi, Camat (Head of Kecamatan) of Parungkuda by H.Toha, also Camat of Cikidang by R.A. Rifa'i, Camat of Cikidang, Yunus as Camat of Cicurug, Mualim Sabana as Camat of Pelabuhan Ratu, Mualim Totong as Camat of Sukaraja, R. Koedi Suriadiharja as Camat of Cikembar, H. Solihin as Camat of Lengkong, Soma as Camat of Jampang Tengah, Jani as Camat of Jampang Kulon, Suyuti as Camat of Ciemas and Utom Bustomi as Camat of Sukabumi (A. Rifa'i, interviewed on March 20th 1999).

The investiture of local official governor from pesantren was more emphasized on the political decision not the bureaucracy aspect, in order to maintain the security after the taking over of the authority (Dadun Abdul Qohar, interviewed on March 12th 2004). Kyai and alim ulama as honored and charismatic religious figure was assumed as the most suitable figure to hold the head of bureaucracy in the lower level which directly interact with the people. They were assumed having an ability to guide the revolution especially in halting the side effect appeared from those who oppose the revolution (Eddie Soekardi, interviewed on January 9th 2004). If there 
was a contra-revolution movement in the local area, they would be facing directly to the kyai or alim ulama which automatically triggered them to face the people.

After the substitution of the office holder, it was also done the handover of the economical assets like Kina manufacture in Tegal Panjang and Gedurahayu, porcelain manufacture in Cirenghas, tile manfacture in Tegal Panjang, tea manufacture in Goal Para, and Swarga dairy manufacture. After controlling the authority with its economical assets, the people of Sukabumi was directed into a new problem, it was facing the allied troops.

\section{Troops Dislocation}

In order to attack and hold the Allies, the commander of the regiment of TKR Sukabumi Lieutenant Colonel Eddie Soekardi assembled the power which involving the soldiers, war patrons, and also pesantren led by kyai dan alim ulama. Beside that, the commander of the regiment had also arranged the troops' placement, then arranged strategy and tactic in attacking Allies convoy (Harry Soekardi, interviewed on March 25th1999).

In the matter of troops dislocation led by commander regimentof TKR Sukabumilieutenant Eddie Soekardi, troops from four Battalion Resimen TKR Sukabumi spread equally, placed in the same important location (Eddie Soekardi, interviewed on February 9th2004). It was also on the troops dislocation, Battalion 1 led by Mayor Yahya Bahram Rangkutiwas placed to patrol along the way of Cigombong-Cibadak Street. Battalion 2 led by Mayor Harry Soekardi, placed along the Cibadak to western part the city of Sukabumi street. Battalion 4 led by Mayor Abdurahmanplaced along the street between the eastern part of the city of Sukabumi until Gekbrong street. Whereas Battalion 3 led by Kapten Anwar, placed along Gekbrong street to Ciranjang street.

Based on those troops dislocation, the convoy attack line measured as $81 \mathrm{~km}$ long was divided into four battlelines including the Commander of Battalion 1 supervising the 12 $\mathrm{km}$ battle line led by Mayor Yahya Bahram Rangkuticommanded four Commander Companythey were Company I led by Captain Tedjasukmanalocated in Cimalati, Company II led by Captain Kusbinilocated in Cikembang village, company III led by Captain Murad Idruslocated in Kompa village, and Company IV led by Captain Mukhtar Kosasihlocated in Cikukulu (Saleh As'ad Djamhari, 1974).They hold the dislocation between Cigombong-Cibadak. The offensive posts were placed in Cicurug, Bojongkokosan, Parungkudaand Ongkrak.

Battalion 2 led by Mayor Harry Soekardisupervised $18 \mathrm{~km}$ battle line. This Battalion organized 4 Companyesthey were Company I led byCaptain Madsachri, CompanyIIled by Captain Husein Alexsyah, Company III led by Captain Juanda, and Company IV led by Captain Dasuki. The troop dislocation from Battalion 2 was placed in offensive posts like a post in Cikukulu, Cisaat, Situ Awi, Cipelang, and Benteng.

Battalion 4 supervised the battle line along $15 \mathrm{KM}$. This Battalion led 4 Commander Companythey are the Commander Company I Captain Djahidi, Commander Company II Captain Sabir, Commander Company III Captain Madsari, Commander Company IV Captain Kabul Sirodz. These troops of Battalion III settled 
the offense posts which filled by the troops from Battalion 4 such as Gekbrong post, Sukaraja post, and Eastern Gate the City of Sukabumi post (Yoseph Iskandar, 1997: 157).

This Battalion 3 Led by the senior captainAnwar supervised the battle line along $35 \mathrm{KM}$. This Battalion led four companies, they were Company I led by Captain Saleh Opo, Company II led by Captain Musa Natakusumah, and Company IV directly led by the commander of the battalion. Battalion 3 settled along the Gekbrong-Ciranjang street. The troops of this Battalion 3 was placed in a strategic place for the offense posts like offense post in Cisokan, Cikijing, Belendung, Sabandar, Warungkondang, and Gekbrong.

Every battalion had a tactical place on strategy to become the center of the offense. Like in Battalion 1, the offense was centered in Bojongkokosan, Battalion 2 centered in Cikukulu, Battalion 4 centered in Gekbrong, Battalion 3 centered in Ciranjang Bridge (Eddie Soekardi, 1999: 6).

The city of Sukabumi was divided into two sectors, they were the western sector for Battalion 2 and the eastern sector for Battalion IV. The roads between the centers of offense emplaced of the people organization led by TKR soldiers aimed to do Operasi Sniper(Sniper Operation). Practically, the battle line along $81 \mathrm{KM}$ was Sniper Line.

\section{Strategy and Tactic}

After the troops dislocation had made, then it was arranged the strategy and tactic in implementing the offensive operation in the field. And when halting the convoy of Allied troops, they used kind of code named mengepung ular berbisa(sieging the poisoned snake) through placing troops into offense posts equally; the purpose of it was to avoid the centered battle on one location and also to avoid the frontal battle. If the frontal battle happened, therefore high risk happened which were many troops died, and also running out of ammunition (Eddie Soekardi,interviewed on June 20th1999).

The attack to the Allies was using hit and run tactic,and Kirikumi. On hit and run, the enemy will be ambushed together, then the troops withdrew to the posts they belong back. Through this way, the troops can secure their power and ammunition safely (A.H. Nasution, 1980: 1-65). In operating the night attack, the troops used Kirikumitactic (Eddie Soekardi, interviewed on June 20th1999) which is an offense tactic to the Allies convoy settled in the heart of the city of Sukabumi, where it was done in close range attack by three of four troops armed with grenades. In each company there should be ten skilled grenade throwers. For the bigger Allies convoys, the attack was added by ranged frontal attack. Whereas for the spread lesser convoys, it was using melee weapons done by TKR members cooperated with Barisan Hizbullah, Sabilillah, Banteng, and other organizations (Soebarna, interviewed on August 27th1999 and April 27th2004).

\section{Troops Consolidation}

In attacking the Allies' power that would be entered the city of Sukabumi, there was consolidation done withthe organizations, civil government, enterprises, Kyaiand Alim Ulamafrom pesantrens dan etcetera (Mukhtar kosasih interviewed on August 27th1999). For the arm division, there was the effort to increase the productivity 
BarataWeapon Manufacture led by Captain Saleh Norman, and to repair the broken weapons, and also to make handy grenade as many as possible (Yoseph Iskandar, 1997: 240).The logistic division was ordered to attempt the uniform, shoes, dan other main logistics need. The transportation division was ordered to attempt the vehicles availability such as used Japanese trucks and plantation trucks. This division also provided motorcycles such as BSA, Norton, Davidson, which were very supporting the couriers' job.

For handling the wounded people, Dr. Hasan Sadikin was ordered to use the city hospital of Sukabumi andthe hospital of Sekarwangi Cibadak maximally. The facility for nursing the TKR members and also other organization members who sick or injured and also red cross troops provided by Dr. Hasan Sadikin (Eddie Soekardi, interviewed on June 20th1999). The communication division cooperated with PTT led by Captain Mu'in oredered to complete the telephone unit to make the communication among battalions' headquarters easier. The financial division ordered to attempt the source of fund to help the Sukabumi Regiment of TKR members' families who will go to battle. The fund was gathered from the donation of the city mayor of Sukabumi Mr. Samsudin, plantation holder, and from people donation.

The consolidation did continuously by the commander of TKR regiment of Sukabumi LieutenantColonel Eddie Soekardiwith the leader of pondok pesantrenknown as the former of Chudanchoand Shodancolike K. H. Hafid, K. H. Syafe'I, M. Sadeli, H. Abdullah and many more. Pesantrensin Parungkudaand
Cicurug area, like Pesantren of Babakan Cicurug, Cipanengah, Pangkalan, Tapos, Pakuwonand other pesantrens in the battle area, its santriswere busy to provide all kinds of traditional melee weapon such as bow, spear, machete, slingshot, all were provided to help the struggle against the Allies (Sanukri, interviewed on June 13th1999). The Kyais were busy to read the particular spell to every weapon used. Even, the santris were bathed through spelled water by the Kyais. They went to battle as Hizbullah fighter.

\section{Halting Allies Convoys}

In facing the arrival of Allies convoy, all battalion commander and companycommander in the TKR regiment of Sukabumi were at the ready to attack (Eddie Soekardi, interviewed on June 20th1999). According to the commander of Battalion I - Yahya Bahram Rangkuti,in halting the Allies convoy, the operation began in Bojongkokosan area (Yoseph Iskandar, 1997: 152).Based on the troops dislocation led by the commander of Battalion I, the center of the troops' power was on the left and right side of the bend road of Bojongkokosan Street, it was because it was strategically purposive. On the left and right side of the bend road of Bojongkokosan street, there was high cliff and irrigation crossing the road, therefore those can be used as a place for cover, with the height of approximately 10 meters highand the cliff was full of shrubs, that place was a perfect place for hiding for the Republican's troops (H. Hudri, interviewed on February 7th2005).

Facing the Allies arrival, sergeant Sahnan, the commander of section IV by the commander of Company II captain 
Kusbiniwas ordered to mobilize his soldiers to make the holes and barricades along the road of Ongkrak Street. On that holes were placed 4 tons land mines. That assignment was finished by the favor of the fighter organization like Sabilillah, Hizbullah, and Pesindo (Saleh As'ad Djamhari, 1974: 12).In Bojongkokosan, the commander of Company III Captain Murad Idrusordered the commander of section I the second lieutenant Muhammad Muchtar located in northern cliff of Bojongkokosan and the commander of section II second lieutenant Djadjang Kusnadilocated in southern cliff in order to make the trap holes and barricades along the Bojongkokosan street. The other sectionsspread along the highway of Cigombong-Cibadak (Mohammad Mukhtar, interviewed on October 1st1996).

The weapons used in the Battle of Bojongkokosan were riffle likes Steyer, Karabyn, Beaumont, Kierop, Sten Gun, Lewis, Keiki, Cuplis, Pistol Parabellum, Colt, long riffle and Molotov Coctailwell known as Keimbing. As well as those weapons, it was also used the traditional weapons such as spears, machete, bamboo pike, slingshot, which used by the youth enrolled as Barisan Hizbullah dan Sabilillah (Ramadhan KH, 1986: 59).

The other power on the Battle of Bojongkokosancame from pesantrenlocated around the battle such as pesantren led by K. H. Jaswadi, K. H. Akhyar, K. H. Hasan Basri, and pesantren led by K. H. Akbar. The kyaischarismatically encourage their santris and the local people around Bojongkokosan such as from Parungkuda, Kompa, Kembang Kuning, Cicurug, Depok, Tapos, Bojong, Cipanengah, Nangela, Pasirmuncang, Pondok Kaso, Pasir Doton and also others area to move to the battle frontline. Before moving to the battle field, they were bathed by the kyai in the spelled pond (dijiad). Also the weapons wished to use such as machete, bamboo pike, and otherweapons were bathed. After they had bathed, they seemed having power and courage. Along with the takbir,santris and people walked to the battlefield (H. Daud interviewed on June 20th2004).

At 16.00,Allied soldiers convoy entered the halting area of Bojongkokosan (Berita Indonesiadated on December 12th1945). When the position of the convoy entered the effective attack range, the offense began after a code of three shots from the commander of Company III Captain Murad Idruswho were responsible for the Bojongkokosan offense post. While shouting takbir, all santris from pesantrenand local people organized as Hizbullahand Sabilillah attacked (The History Division of Kodam III Siliwangi, 1985: 2).

As the result of the Republican attack in Bojongkokosan, the Allies troops halted for approximately two hours(Saleh As'ad Djamhari, 1974: 12). According to A.E. Kawilarang (Ramadhan KH, 1986: 59),to face the fighter in Bojongkokosan, Allies asked its air power. Toward Maghribtime (dusk), the Allies air reinforcement came, the Allies' planes skillfully attacked the fighter (Bisri, interviewed on June 9th1999). The loss of Allies from the battle of Bojongkokosan was 18 destroyed vehicles, died drivers, and 100 died Gurkha soldiers (Berita Indonesia, 12 December 1945).

Under the shadow of the guerilla fighter, the Allies convoy attempted to enter the city of Sukabumi. Hardly, they reached the 
downtown at 24.00 (Soebarna, interviewed on March 17th1999 and April 20th2004). After arriving in the city of Sukabumi, they were rested in front of the Hotel of Victoria (Yoseph Iskandar, 1997: 191). Although they had arrived in downtown, the death was still haunted. Along with military operation plan, in the downtown was done troops dislocation. The troop spread in every corner of the city. They were at the ready to attack the arriving convoy.

In the next day after the battle in Bojongkokosan, there was happened a bombing attack to the city of Cibadak (A.J.F. Doulton, 1951: 284)by the Royal Air Forcebegan at 08.30. That bombing attack happened as the Allies counter attack for the Republican attack to the Allies convoy between Bojongkokosan and Sukabumi. The reason why Cibadak was bombed because that city was assumed by the Allies as the main defense place of the troops in Sukabumi (Eddie Soekardi, interviewed on February 9th2004). The result caused by that bombing attack was the destroying of Cibadak city (Berita Indonesia, December 14th1945). The war victims were evacuated to the Sekarwangi Hospital by the Red Cross groups led by Dr. Hasan Sadikin (Isak, interviewed on June 3rd1999), and died victims were buried behind the hospital.

After the Allies convoy had arrived in the heart of Sukabumi city, the commander of Sukabumi TKR regiment ordered the commander of Battalion III captain Anwar who responsible for the Gekbrong-Ciranjang area, to increase the steadiness of his troops. Proper with the order from the commander of the regiment, captain Anwar strengthened the trops placement along the Ciranjang-
Gekbrong high street. The commander of Battalion III emplaced Companytroops of Captain Musa Natakusumah, fully steady on the left and right side of the Gekbrong, Warung Kondang, Leuwi Goong streets until the bridge of Cikaret. The company of Captain Dasoeni Zahidplaced in Cikijing to Cisokan'sbridge in Ciranjang. The company of Captain Saleh Opo was fully steady along the Pacet highway to secure the way from the possibility of the Allies troops taking the Puncak way. The commander of Battalion III Captain Anwar directly led a platoon of troop assisted by the Second Lieutenant Abubakar (Aboebakar, interviewed on August 27th1999 and March 17th2004).

In order to help the troops halted in Sukabumi, the Allies main headquarter in Jakarta ordered Allies headquarter in Cimahi Bandungto reinforce consists of Battalion 3/3 Gurkha Rifles. The troop from Cimahi was departed to Sukabumi to help Allies troop halted in the city of Sukabumi on December 11th1945. Thi reinforcement troop armed with several Shermantank as a troop guar, Panser Wagon, Brencarier, and troop's trucks empowered by the stealth air plane.

The fate of Battalion 5/9 Jats troops which was halted and attacked fully by the fighters in Cigombong-Sukabumi way, also experienced by the Battalion 3/3 Gurkha Riflestroops from Bandung. Pasukan Battalion 3/3 Gurkha Riflesfrom Cimahiwhich is ruined continuously attempting to reach the city of Sukabumi. They struggled in order to assembly with the other Allies troops hated on that city. After having a rest, with the rest of power, they continued to leave the city of Sukabumi, to continue their journey to Bandung. Before leaving Sukabumi, they 
contacted with Regiment of Sukabumi TKR and asked guarantee that the Republican troops would not distract the journey (Eddie Soekardi, interviewed on June 20 1999, and February 9th2004).

According to Doulton (A.J.F. Doulton, 1951: 294),this second convoy of Allies troopswasledby LieutenantColonel Bikram Dev Singh Gill successfully entered to the Sukabumi city. That convoy was guided by Sherman tanks followed by panser wagon and Brencarier (Isak, interviewed on June 13th1999). The journey of that convoy was very slow,it was because they had interruption from the guerillas (Yoseph Iskandar, 1997: 254).

The Allies convoy which successfully entered the city of Sukabumi was net given a chance to rest. They directly attacked by 3 platoons of troops from the company of Captain Madsachriassisted by two platoons of troops of Company of Captain Mochtar Kosasih and two troops platoons of company of Captain Djahidi which directly led by the commander of the Battalion named Mayor Abdurahman. The attack to Allies troops in the heart of Sukabumi city was supported by the troops from Company of Captain Kabul Sirodzwho organized attack from Hizbullah, Sabilillah, Banteng, Pesindo, and others. The battle in that city's heart was at 21:30, begun by attacking the Allies convoy in Benteng Street (Gelora Rakyat, March 12th1946). Along the night on March 1oth and 11th1946 there was happened battle almost in eery corner of the Sukabumi city. The grenade thrower special troops from the company of Captain Madsachri continuously hitting the Allies trucks stayed around the Kabupaten, Victoria Hotel, and Selabintana (Soebarna, wawancara March 17th1999 and April 27th2004). Battle in Sukabumi made the Allies troops from Patiala Battalion distressed (A.J.F. Doulton, 1951: 295).

On Sunday night March 11th1946 at 20.00, all lamps in Sukabumicity suddenly shut by PLN (name of the electricity company in Indonesia). After the city dark, company from TRI regiment of Sukabumi along with barisan perjuangan rakyat began to rotate to siege the Allies convoy from Patiala Battalionwhich is located in the center of Sukabumi city. The trap attack was done by Hizbullah, Sabilillah, Pesindo, Banteng, organized the Companyof Captain Kabul Sirodzfrom Battalion 4 which moved from square northern area.

From every Allies vehicle, the lights were lit pointing to north. The Patiala Battalionformation was concentrated to face the attack possibility from the south. Instead, the Allies trop concentration was broken because beyond their prediction, Kirikumitroops from the Companyof Captain Mukhtar Kosasihmoved in parallel from the western downtown area. The little companies of grenade thrower which consist of three to four soldiers without using shoes sneaked crawled behind. Kirikumi company led by Captain Dasuki from Battalion 2 moved from south west then continue attacking the Patiala soldiers. Exactly at 23.00, the attack was altogether stopped. The result of that battle in Sukabumi causing at least 40 Allies soldiers died (Gelora Rakyat, March 14th1946).

The reaction towards that battle came from the Main Allies Headquarter in Jakarta. By the airplane, Allies spread the pamphlet contains the ultimatum that the fighter must stop attacking the Allies convoy. If it is not stopped, therefore Allies will attack through air force, artilleryand others machine gun 
(Gelora Rakyat, March 16th1946). That ultimatum did not decrease the faith of Sukabumi's fighters to face the Allies attack.

In order to resolve the battle crisis in Sukabumi, the Main Headquarter of Allies in Jakarta ordered Brigadier N.D. Wingrove, an English high officer settled in Bandung to move toward Sukabumi (A.J.F. Doulton, 1951: 296). That High Officer departure brought a convoy of Brigade I troops consists of 2 companies of genie troops, includes its guards.

The information of reinforcement sent by Allies from Bandung accepted by the Commander of Battalion 3 Captain Anwar. In facing the Allies troops, Captain Anwar concentrate his troops in Cisokan bridge (Abu Bakar, interviewed on April 10th 1999). Some of troops placed in Karang Tengah, Sabandar, Belendung, and Cikijing were withdrew to the front line to join with the company of Dasoeni Zahid. The battle in Cisokan was led directly by Captain Anwar (Abu Bakar, interviewed on April 10th 1999).

Brigadier N.D. Wingrove was not be able to continue his journey, he was halted in front of the Office of Kewedanaan of Ciranjang (Yoseph Iskandar, 1997: 302). Brigadier N. D. Wingrove informed that the troops' convoy which should reinforce actually halted and attacked in 30 kilometer position before Sukabumi instead (A.J.F. Doulton, 1951: 296). The commanders who were halted in Sukabumi suggested that Brigadier N. D. Wingrove does not continue his journey.

\section{Sukabumi Under Full Attack}

Preparing Allies' full attack toward Sukabumicity, thecommanderofSukabumi regiment of TRI lieutenant colonel Eddie Soekardi did the troops re-dislocation.
Every commander of battalion ordered to do consolidation of power in their camps. Battalion I in Cikukulu, Battalion II in Cisaat, Battalion IV in Cipoho. Close to dusk time, all special troops of Kirikumi of TRI Regiment Sukabumi had spread in the attack base such as in Situ Awi, Gunung Puyuh, Bunut, Kebon Jati, Ciaul, Cipelang, Nanggeleng, Tipar, Cipoho, Nyomplong, Benteng, and other bases (Harry Soekardi, interviewed on January 21st 1999). All citizens of Sukabumi whose house were close to the Allies troops' posts secured. The civilian helped the fighters' moral and material (Eddie Soekardi Soekardi, interviewed on August 27th 1999 and February 9th 2004).

Allies troops' power in Sukabumi consists of four large companies' soldiers they were Patiala Battalion, Rajputama Rifles, Squadruan 13 Lancer, and Grenadier. They were supported by several supporting power consists of several Sherman tanks, panser wagons, Brencariers, and hundreds transporter trucks. Those were emplaced all city corners (A.J.F. Doulton, 1951: 296).

To expel Allies from Sukabumi, the only one way was attacking massive attack to Sukabumi city which was become the Alies post. The massive attack began at 20.00 WIB (abbrev from Waktu Indnonesia Bagian Barat/West Indonesia Time), when the electricity was shut down in all city to help the fighter doin night attack. That thing made the Allies troops keep busy. The frenzy happened in all streets in the city. They kept patrolling steadily, waiting the offensive attack by the guerilla fighters. They wait the attack; nevertheless there was no sign that there will be an offense attack from Repubican fighters.

The Republican Soldiers from all companies of Sukabumi TRI regimen of 
Kirikumi sneaked tried to reach Allies convoy formation located on the side of the Sukabumi city's streets. In their movement, the Kirikumi soldiers were organized by the commander each of their Company Commander. It was done until 19.58, all Allies convoy settled in the downtown had been in the siege radius of Kirikumi soldiers. Captain Madsachri from Battalion 2 along with his Kirikumi troops had been spread tidily around the location of Schuttervaer Bakery Shop. On that place, the commander officers from Patiala Battalion, Rajputana Rifles, Squadron 13 Lancer, and Grenadier were gathered.

The battle began through grenade attack targeting the Allies Commander, continued by rapid attack by spread Kirikumi soldiers. The Allies' companies were ambushed by Captain Madsachri and his men (Madsachri, interviewed on July 13th 1999). The Allies troops which got sudden attack was losing control. They had not given the counter attack, they were died slashed and chopped by the sharp Kirikumi's machete. On every dark night corner, barisan pejuang rakyat swing marble bullet through their slingshot hit the forehead, nose, eyes, and so on.

The Kirikumi attack ran for long time. The Allies counter attacked the fighter by shooting them. TRI just countered the Allies attack through throwing grenades. On that night battle, attacking by using machete was assumed more efficient in killing the Allies soldiers. The Allies troops who tried to flee to the housing area was just like hunted animal, they were hunted, and then murdered (Soebarna, interviewed on April 27th 2004). But there were also the Alies soldiers who saved by the civilian after knowing that the Allies soldiers are Moslem, commonly they were from Pakistan and shouting takbir when fleeing from battlefield (Misbah, interviewed on June 18th 2004, and January 5th 2005).

Arrounf 21.30 WIB, the combination between attacking and ambushing by the fighter which consists of regular soldiers, Hizbullah, Sabilillah, Barisan Banteng, or local people became more effective and aggressive. The sharpness of machete, and thrown grenades, arch bolt, marble bullet, or even stones became a combination ruining the defense of of the Allies lines settled in Sukabumi. It made the situation in the heart of Sukabumi city became hysteric and spooky. The light of flame from the various Allies' machine gun blew like fireworks (Mukhtar Kosasih, interviewed on August 27th 1999). When the attack to Allies convoy was assumed fairly enough, the commander of battalions withdrew their troops to return to their posts. At 23.00 WIB the battle was almost finished. The battle was finished at 23.30 WIB

The massive attack toward the city of Sukabumi held on that night made the Allies moral dropped. They had not used cannon, war machine, and other heavy artilleries. It was just because there was no time to use those all; therefore those machines lied useless in Allies posts. The Allies officers using the radio was busy to call the Allies main headquarter. They reported the casualties they had. They assumed that the city of Sukabumi was terrible city spreading the death.

\section{War Strategy and Negotiation}

The Allies bombing on Cibadak was not affecting the Sukabumi fighters' courage. They even did the counter movement by attacking the Allies convoy marching to 
Bandung. Considering the safety, Allies decided not to continue the journey, and stayed in the heart of Sukabumi city (Edie Soekardi, interviewed on February 9th 2004).

In handling the trapped Allies troops in Sukabumi, the Allies called the Prime Minister Sutan Syahrir. The Prime Minister said emphasizing the Indonesian government act, that principally wuld help the international task. Sutan Syahrir mentioned that if the Allies convoys deserved not to be disturbed by the Sukabumi fighters, therefore the Allies should consequently toward the pact which has been agreed that the securing task would be given to TKR.

In solving this terrible situation in Sukabumi, the Allies Main Headquarter sent Mayor Rawin Singh from the headquarter of English Brigade in Bogor to supervise the location of Allies troops and should meet the local government of Sukabumi to discuss about negotiation (Yoseph Iskandar, 1997: 203). Escorted by Jats Battalion officers, that Allies delegation arrived at 02.30 WIB meeting the city Mayor of Sukabumi. In the Mayor's place, they were also arrived Dr. Abu Hanifah, R. Didi Soekardi, and Bupati of Sukabumi Mr. Harun.

The negotiation between the Allies delegation and the Republican Delegation held in Mayor's place. The negotiation was opened by Mr. Samsudin as the host. According to Mr. Samsudin, he as the Civil Government principally was still consequent toward the pact between Indonesian and Allies. Nevertheless, the fact in the field should be thought by the Allies why does it happen. If the Allies consequent toward the International task they have, the blockade and attack toward the Allies troops which bring the logistic supply to APWI in Bandung would not be happened. The the City Mayor Samsudin's message on that meeting was understood by Mayor Rawin Singh, and he will report it to the Allies main headquarter in Jakarta. On that occasion, the Allies delegation asked to the City Mayor to persuade the Republican troops led by Sukabumi TKR Regiment to let the Allies convoy left Sukabumi and continue the journey to Bandung (Eddie Soekardi, interviewed on February 9th 2004).

The City Mayor of Sukabumi's moderate attitude in facing the Allies delegation was different with the Bupati of Sukabumi Mr. Harun who acts confronted. Mr. Harun rejected to do negotiation with the Allies as well did bye the Prime Minister Sutan Syahrir. In facing the Allies, the Bupati of Sukabumi Mr. Harun tended to face them by war relied on people, especially Pesindo such as the offense attack in Cicurug, although there were many casualties in the people side caused the incoordination with the TKR.

The disputation between City Mayor of Sukabumi Mr. Samsudin and the Bupati of Sukabumi Mr. Harun regarding the Allies convoy problem could be neutralized after the city mayor telling that the convoy problem is not the civil government affair. Mr. Samsudin assumed that the convoy problem is the military affair; therefore it should be discussed with the TKR. After being called by the City Mayor, the Commander of Sukabumi TKR Regiment Lieutenant Colonel Eddie Soekardi assisted by Mayor Abdurahman arrived in the meeting place. On that meeting, the commander stated his view regarding the 
Allies convoy problem. Lieutenant Colonel Eddie Soekardi assumed that the one who has the military charge is not the civil government.Basically, theTKRobeyedupon the pact between the central government and the Allies, but it was depended on the Allies consequence toward the pact. If the Allies in implementing the APWI problem does not involve the TKR regarding the supply sending and escorting, there will be blockading and attacking toward the convoy (Eddie Soekardi, interviewed on February 9th 2004).

Infacing the Allies, theleader commander of Commandment I of TKR in West Java Mayor General Didi Kartasasmita used the strategy combination between negotiation to attack and attack to negotiate (Eddie Soekardi, interviewed on February 9th 2004), that is attempting the diplomacy task between Republic of Indonesia Government with the Allies run successfully, whereas in the other side giving the trust to TKR Regiment of Sukabumi to attack the Allies (Ramadhan, 1986: 1).

The meeting between Allies and Indonesian delegation was held on December 24th 1945, continued on January 9th to 10th 1946, and later on January 17th to 18 th 1946 in The Allies Headquarter in Jakarta. The discussion was about the evaluation of the aid assistance from the Indonesian Government to the Allies in attempting the Japanese troops and APWI evacuation APWI. On that meeting, the Indonesian government was delegated by Mayor General Soedibjo and ieutenat Colonel Latief Hendraningrat. Whereas from the Allies, delegated to the Head of AFNEI staff Brigadier N.D. Wingrove and Officer Staff Lieutenant Colonel van Der Post (Yoseph Iskandar, 1997: 93).
From that meeting between Allies and the Republic of Indonesia Government, it was submitted an agreement. In the other side, the battle between the Allies and the TKR and Indonesian fighters was still continue. This condition mde the Allies confused, no war no peace (Eddie Soekardi, interviewed on February 9th 2004).

The momentum of Bojongkokosan battle which happened on December 9th 1945 was an important event which starting the glorious victory of TKR war strategy, and also the triumph of International Moral Diplomacy for de facto of the Republic of Indonesian Government. The battle happened on March 10th to 14th 1946 along the Cogombong - Sukabumi - Ciranjang high way and the event of Bandung Lautan Api on March 24th 1946 had forced the Allies to persuade the Republic of Indonesia Government to negotiate in Jogjakarta on April 2nd 1946. Theat meeting discussed the operation of APWI evacuation. Based on the negotiation result known as Yogyakarta Agreement, it was established an executor agency named as POPDA. This agency consists of the government instances, cored with TRI which firstly led by Mayor General Soedibjo who later succeeded by Mayor General Abdoel Kadir.

\section{Conclusion}

The revolutionin Sukabumi was azenith of the insatisfaction and the disappointing expression toward the olonial government policy whether it was on political, social, econmical and cultural that make the people of Indonesia suffering, especially the people of Sukabumi. The political, economical, social, or cultural colonization, and the Proclaim of Republic of Indonesia 's independence, and also the nationalism 
encouraged by the kyai or ulama as a leader of pondok pesantren and also by the nationalists whether it is local nationalists and or the nationaist from came from Jakarta, were the supporting factors of the revolution birth Sukabumi.

The revolution in Sukabumi was influenced by Ideology of Islam, Socialist, Communist and Nationalist. The dynamical revolution in Sukabumi ran fast after there was interaction between the local elites in Sukabumi and the movement group especially the nationalist group who came to Sukabumi.

Revolution in Sukabumi began with the mmass mobilization which involved all the revolution power whether it was from the pondok pesantren, the youth grouped as Hisbullah, Sabilillah, Pesindo, Badan Keamanan Rakyat, political figures, and many others.

Revolution in signed with the taking over of authority and colonial authority symbols from the Japanese hand, followed by the succession of the government officer on the kabupaten level, kotamadya (municipal city) until kecamatan (district). Then it was continued by taking over the economical assets such as enterprises and plantations, for example Cikotok Gold Mining Enterprise, the Electricity Enterprise, Tegalpanjang, Gedurahayu, Cireunghas, Cirohani Plantation and etc.

Thezenith of Sukabumirevolutionagainst the Alies along the Cigombong-Ciranjang high way track triggered several battles such as the Battle of Bojongkokosan which caused the Allies air force bombing of Cibadak, the Battle of Gekbrong, and the Massive Attack toward the city of Sukabumi which involving the soldiers, organizations, alim ulama and santri from pesantren.

Revolution in Sukabumi could not be separated from the role of kyai and ulama as the leader of pondok pesantren. They had the ability to encourage the revolution spirit burning the mass emotion. The success of kyai in mass mobilizing was because they used the religion's language. Kyai and ulama burnt the nationalism and patriotism spirit of the santri and local people around pesantren using the concept of jihad fi sabill Allah or war in the name of Allah.

The success of revolution in Sukabumi was because there was the synergy between kyai rolled as the mass mobilizer and the ini Sukabumi Regiment of TKR soldiers led by Lieutenant Colonel Eddie Soekardi who rolled as coordinator and executor in the field.

Revolution in Sukabumi which was involving all peoples had given impact to the Revolution of Indonesia. It was proved by the solving through diplomacy between the Republic of Indonesia delegation represented by Haji Agus Salim as a minister of international affair and I. C. A. Lauder which was attempting to solve the problem in Sukabumi through diplomacy.

The Allies problem solving in Sukabumiwas finished through politik dua kaki, which means solved through diplomacy, and solved through war in the field. It was just because the Allies disobey the pact to uninvolved Dutch in submitting its task to evacuate APWI. 


\section{REFERENCES}

Benda, H. J. dan Ruth T. Mc. Vey. (1960). The Comunist Uprising of 1926-1927 in Indonesia. Key Document. Ithaca Cornel University .

Djamhari, S. A. (1974). The Battle of Bojongkokosan Cibadak, December 9th 1945. Makalah Kongres IAHA ke VI. Yogyakarta.

Iskandar, M.dkk.(2000). PeranEliteAgama Pada Masa revolusi Kemerdekaan. Jakarta.

Iskandar, M. (2001). Para Pengemban Amanah: pergulatan pemikiran Kyai dan Ulama di Jawa Barat 1900-1945. Mata bangsa: Yogyakarta.

Iskandar, Y. (1997). Pertempuran Konvoy Sukabumi-Cianjur 1945-1946. PT. Sukardi LTD: Jakarta.

Jaya, R. (2002). Sejarah Sukabumi. Sukabumi.

Kurasawa, A. (1993). Mobilisasi dan Kontrol (terjemahan Kunta Rahardjo judul asli Mobilization and Control). Jakarta.

Kahin, A.R. (1979). Strunggle for Independence; West Sumatra in The Indonesian National Revolution 1945-1950. Ithaca: New York Cornel University.

Kahin, G. Mc T. (1995). Nasionalisme dan Revolusi di Indonesia. (terjemahan Nin Bakdi Soemanto judul asli Nationalism And Revolution In Indonesia). Jakarta: UNS Press,

Lukas, A. E. (1989). Peristiwa Tiga Daerah: Revolusi dalam Revolusi. Jakarta: Pustaka Utama Grafiti.

Lubis, N. H. (1998). Kehidupan Kaum Menak Priangan 1800-1942. Bandung: PIKS.

Mastuhu. (1994). Dinamika Sistem Pendidikan Pesantren. Jakarta: INIS.
Nasution,A. H.(1980).Pokok-PokokPerang Gerilya dan Pertahanan Republik Indonesia di Masa Lalu dan Masa Yang Akan Datang. Bandung: Angkasa.

Poeze, H.A. (1999). Pergulatan Menuju Republik: Tan Malaka 1925-1945. Jakarta: Grafiti.

Panitia Pembangunan Monumen Perjuangan 45 Kabupaten Sukabumi. (1986). Sejarah Peristiwa Bojongkokosan. Pemda, Sukabumi.

Pemerintah Kabupaten Sukabumi. (1986). Sejarah Kabupaten Sukabumi.

Reid, A. J. S. (1981). Revolusi Sosial : Revolusi Nasional, Prisma Th. X, No. 8 Agustus.

Soekardi, E. (1999). Pertempuran Bojongkokosan. Makalah. Bandung.

Smail, J. R. W. Bandung in the Early Revolution 1945-1946 : a Study in the Social History of the Indonesian Revolution Ithaca New York: Cornel University.

Steenbrink, K. A. (1984). Beberapa Aspek Tentang Islam di Indonesia Abad ke-19., Jakarta: Bulan Bintang.

Surianto, R.M. Agustinus dkk. (1998). 50 Tahun Keuskupan Bogor dalam Lintasan Sejarah. Bogor: Grafika Mardi Yuana.

Suyatno. Feodalisme dan Revolusi di Surakarta 1945-1950. Prisma Th VII No.7.

Syahrir, S. (1990). Renungan dan Perjuangan. Jakarta.

Vey, Rut T. Mc. "Introduction. (1978). Local Voice Central Power" in Rut T. Mc. Vey. Southeast Asian Transitions: Approaches Throught Social History, New Have dan London, Yale university Press. 
William, M. C. (1990). Comunism, Religion, and Revolt in Banten, Ohio University Center for International Studies. Monographs in International Studies Southeast Asia Series No. 86 Ohio 1990.

\section{interviewed}

Soebarna, interviewed on March 17th 2004

Eddie Soekardi, interviewed on April 4th 2004

A.Rifa'i, interviewed on March 2oth 1999

Dadun Abdul Qohar, interviewed on March 12 th 2

Harry Soekardi, interviewed on March 25th1999

Natakusumah, interviewed on June 24th1999

Eddie Soekardi, interviewed on June 2oth 1999
Soebarna, interviewed on August 27th1999 and April 27th 2004

Mukhtar kosasih interviewed on August 27th 1999

Sanukri, interviewed on June 13th 1999

H. Hudri, interviewed on February 7th 2005

Mohammad Mukhtar, interviewed on October 1st1996

H. Daud interviewed on June 20th 2004

Isak, interviewed on June 3rd 1999

Aboebakar, interviewed on August 27th 1999 and March 17th 2004

Madsachri, interviewed on July 13th 1999

Misbah, interviewed on June 18th 2004, and January $5^{\text {th }} 2005$

Mukhtar Kosasih, interviewed on August 27th 1999 